\title{
INFLUENCE OF THE INCREASING WEIGHT OF THE BACKPACK ON THE BALANCE OF MOVEMENT TO PRIMARY SCHOOL STUDENTS
}

\author{
Nan ZHOU ${ }^{1,2}$, Wuyong CHEN $^{1 * *}$, Jin ZHOU $^{1}$, Luming YANG ${ }^{1}$ \\ ${ }^{1}$ National Engineering Laboratory for Clean Technology of Leather Manufacture, Sichuan University, Chengdu, 610065, China \\ ${ }^{2}$ Guangzhou Shiling Leather \& Leather Products Investigation Center, No.6 Yangguang Road Shiling Town, Huadu district, \\ Guangzhou city, Guangdong province, 510850, China
}

Received: 07.12.2018

Accepted: 29.05 .2018

https://doi.org/10.24264/Ifj.18.2.7

INFLUENCE OF THE INCREASING WEIGHT OF THE BACKPACK ON THE BALANCE OF MOVEMENT TO PRIMARY SCHOOL STUDENTS

ABSTRACT. Nowadays, the backpack is becoming more and more important in people's daily life in our society. It has aroused the concern of the community that primary school students carry heavy bags. Heavy loading may cause some problems, like spinal, shoulder and back pain, etc. Consequently, it will affect the growth and development of students directly or indirectly. Thereby, the aim of this paper was to understand the influence of increasing the weight of the backpack on the balance of movement, and to explore the effect of heavy loading on the growth and development of those subjects. 100 healthy primary school students (7-12 years old) were recruited and they were guided in walking with a backpack loading of $5 \%, 10 \%, 15 \%, 20 \%$ and $25 \%$ body weight. Their kinematic and kinetic data were measured by Footscan plantar pressure system and 3D motion capture. Parameters of center of pressure and vector angles within two lower limb joints were calculated to quantify the relationship between the loading and balance. Our results show that an increase of weight of the backpack has limited effect on the track of the center of pressure, and pupils can cope with the balance risk brought by the increase of load. In order to maintain balance control, students adjust their posture to eliminate the balance risk factors caused by loading. While increasing of loading had a great effect on body posture, 15\% BW (Body Weight) loading could be considered to be a safe value.

KEY WORDS: backpack load; center of pressure; vector angle; motion balance; primary school students

INFLUENȚA CREȘTERII GREUTĂṬII RUCSACULUI ASUPRA ECHILIBRULUI ÎN MIȘCARE AL ELEVILOR DE ȘCOALĂ PRIMARĂ

REZUMAT. În prezent, rucsacul devine din ce în ce mai important în viața noastră de zi cu zi. Acest lucru a stârnit îngrijorarea comunității privind greutatea genților transportate de elevii de școală primară. Supraîncărcarea poate provoca unele probleme, cum ar fi durerile de coloană, umăr și spate etc. În consecință, aceasta va afecta creșterea și dezvoltarea elevilor în mod direct sau indirect. Astfel, scopul acestei lucrări este de a înțelege influența creșterii greutății rucsacului asupra echilibrului în mișcare și de a explora efectul supraîncărcării asupra creșterii și dezvoltării acestor subiecți. Au fost recrutați 100 de elevi de școală primară sănătoși (cu vârsta cuprinsă între 7 și 12 ani) și li s-a cerut să se deplaseze cu un rucsac cu 5\%, 10\%, 15\%, 20\% și 25\% din greutatea lor corporală. Datele cinematice și cinetice ale acestora sunt măsurate cu sistemul de presiune plantară Footscan și prin captarea 3D a mișcării. S-au calculat parametri precum centrul de presiune și unghiurile dintre vectori la două articulații ale membrelor inferioare pentru a cuantifica relația dintre încărcare și echilibru. Rezultatele noastre arată că creșterea greutății rucsacului are un efect limitat asupra traiectoriei centrului de presiune, iar elevii pot face față riscului de dezechilibru cauzat de creșterea greutății. Pentru a menține controlul asupra echilibrului, elevii își ajustează poziția pentru a elimina riscul de dezechilibru cauzat de încărcare. Deși creșterea greutății a avut un efect pozitiv asupra posturii corpului, încărcarea cu $15 \%$ din greutatea corporală ar putea fi considerată o valoare sigură.

CUVINTE CHEIE: încărcare rucsac; centru de presiune; unghi dintre vectori; echilibru în mișcare; elevi de școală primară

L'INFLUENCE DU POIDS CROISSANT DU SAC À DOS SUR L'ÉQUILIBRE EN MOUVEMENT CHEZ LES ÉLÈVES DE L’ÉCOLE PRIMAIRE

RÉSUMÉ. De nos jours, le sac à dos devient de plus en plus important dans la vie quotidienne. Ceci a soulevé l'inquiétude de la communauté concernant le poids des sacs portés par les élèves de l'école primaire. La surcharge peut causer certains problèmes, comme une douleur à la colonne, à l'épaule et au dos, etc. Par conséquent, la surcharge affectera directement et indirectement la croissance et le développement des élèves. Ainsi, le but de cet article est de comprendre l'influence du poids du sac à dos sur l'équilibre en mouvement et d'explorer l'effet de la surcharge sur la croissance et le développement de ces sujets. 100 élèves d'école primaire en bonne santé (âgés de 7 à 12 ans) ont été recrutés et invités à se déplacer avec un sac à dos avec $5 \%, 10 \%, 15 \%, 20 \%$ et $25 \%$ de leur poids corporel. Leurs données cinématiques et cinétiques ont été mesurées avec le système de pression plantaire Footscan et par la capture de mouvement 3D. Des paramètres tels que le centre de pression et les angles entre les vecteurs à deux articulations des membres inférieurs ont été calculés pour quantifier la relation entre la charge et l'équilibre. Nos résultats montrent que l'augmentation du poids du sac à dos a un effet limité sur la trajectoire du centre de pression, et les étudiants peuvent faire face au risque de déséquilibre causé par le gain de poids. Pour maintenir le contrôle de l'équilibre, les élèves ajustent leur position pour éliminer le risque de déséquilibre causé par le chargement. Bien que le gain de poids ait eu un effet positif sur la posture du corps, une charge de $15 \%$ du poids corporel pourrait être considérée comme une valeur sûre.

MOTS CLÉS : chargement du sac à dos ; centre de pression ; angle de vecteur ; l'équilibre du mouvement ; élèves de l'école primaire

\footnotetext{
* Correspondence to: Wuyong CHEN, National Engineering Laboratory for Clean Technology of Leather Manufacture, Sichuan University, Chengdu, 610065, China, Tel.: 86-28-85405237; fax: 86-28-85405237. E-mail address:wuyong.chen@163.com
} 


\section{INTRODUCTION}

Backpack load is becoming more and more important in people's daily life in our society. It has aroused the concern of the community that primary students carry heavy bags. Heavy loading may cause some problems, like spinal, shoulder, and back pain, etc. Consequently, it will affect the growth and development of students directly or indirectly [1, 2]. It was found that back pain was common in primary school students [3].

Backpack load inflicts external loading on a child's body and it changes the position of the center of gravity of the body. In order to maintain balance control and resistance, children would adjust their gait and posture. The method of biomechanical analysis was applied to analyze the body changes with different weight of the backpack of primary school students, according to the principle of biomechanics, so as to explore the influence on primary school students' growth and lay the foundation of the optimal designing of all kinds of healthy products. In current literature, scholars studied the effect of a backpack on human body posture and gait, such as plantar pressure/body deviation angle/muscle tone, etc. In accordance with the previous experimental results, the weight of students' backpack should be less than $10 \%$ of body weight [4], and $15 \%$ of body weight was the critical safety value [5].

Balance in movement is the steady state, the body adjusted the action, posture, or size of the force to maintain the steady state when the body imbalances, this is a complex process of dynamic balance. The selection of optimal position depends on the right combination of the target motion stability and flexibility. Balance control is an important function of the human body and its external behavior is the ability to keep stability of posture under any loading. The center of mass and center of pressure can reflect the ability of balance veritably.

Equilibrium and the angle dynamics were the most commonly used mechanics method to research balance. The research of the weight of children's backpack of Pau et al. showed that with the increasing of weigh, the center of pressure (COP) track length became longer and moved forward, and the lateral displacement of COP became smaller, these increased the discomfort and structural damage of the feet [6]. Research of Rugelj and Sevsek showed that COP track length and displacement increased with the weight of backpack linearly $[7,8]$. The increasing of weight of a backpack would affect balance ability in multi-aspect, and body posture control often assessed by quantifying the range of the center of pressure. Singh and Koh assessed 17 pupils walking on a treadmill under different backpack weights and they suggested that with the increasing weight of the backpack, the body leans forward gradually and the increasing of weight would lead to changes in body posture [9]. Meyers-Rice et al. [10] analyzed the distribution of plantar force and postural sway in a sample of 10-year old children who carried a backpack of $5 \%, 10 \%$ and $15 \%$ of their body weight under static conditions. However limitations existed in the current studies: (1) the number of subjects used in the above were very few, which would cause deviation of the experimental results; (2) there was little study about the effect of backpack on motion balance in China; (3) no description on the relationship between the backpack weight and movement balance, and less quantitative evaluation index data representation.

On account of the limit of current studies, our study recruited 100 healthy primary school students in China aged between 7 and 12, and they were guided in walking with a backpack loading of $5 \%, 10 \%, 15 \%, 20 \%$, and $25 \%$ body weight. Their kinematic and kinetic data were measured by Footscan plantar pressure system and 3D motion capture. Then the influences of the backpack weight on the motion balance of pupils were evaluated quantificationally.

\section{METHODS}

\section{Subjects}

The study recruited 100 healthy primary school students aged between 7 and 12 (Table 1) who came from a primary school at Guangzhou, Guangdong province, China. The inclusion criterions shown below were: (1) walking independently without support including 
orthopedic instrument; (2) no scoliosis; (3) feet without trauma. The aims and methods of this test were first explained to patients' parents and a formal approval was obtained before the test. Furthermore, this study was approved by the ethics committee of the university and all procedures were following with the principal of Helsinki Declaration.

Table 1: Demographic Information of Subjects

\begin{tabular}{ccccccc}
\hline Age & 7 & 8 & 9 & 10 & 11 & 12 \\
$\mathrm{~N}$ & 14 & 14 & 21 & 26 & 20 & 5 \\
Height/cm & $121 \pm 9$ & $127 \pm 10$ & $131 \pm 11$ & $137 \pm 16$ & $142 \pm 10$ & $145 \pm 6$ \\
Weight/kg & $22.0 \pm 6.4$ & $27.8 \pm 12.6$ & $27.3 \pm 11.2$ & $30.5 \pm 11.4$ & $32.0 \pm 9.7$ & $34.7 \pm 7.6$ \\
BMI & $14.9 \pm 3.6$ & $16.9 \pm 6.3$ & $15.9 \pm 4.1$ & $16.2 \pm 5.3$ & $15.9 \pm 2.8$ & $16.5 \pm 2.7$ \\
\hline
\end{tabular}

\section{Devices and Settings}

Children's plantar pressure was measured by Footscan pressure plate (one meter plate, RSscan Int., Belgium), they were guided in walking with a backpack load of $5 \%, 10 \%, 15 \%$, $20 \%$ and $25 \%$ body weight respectively. The scanning frequency of this system is $250 \mathrm{~Hz}$, pressure sensor density is $4 / \mathrm{cm}^{2}$, and the range of measure is $0-200 \mathrm{~N} / \mathrm{cm}^{2}$. A two-step initial protocol was performed by the children and they were guided in walking with their selected speed through the pressure plate which was located in the middle of six-meter-long track [10]. Before the measurement, the system was calibrated: first a subject's weight was measured, then allowed to walk with their selected speed through the pressure plate, and the test system would adjust the weight value of actual and theory automatically so as to calibrate; and then three to five minutes warm up was provided.

Codamotion (Odin, Charnwood Dynamics Ltd, UK) was used to collect the motion track of key points with body movement. Before the measurement, the system was calibrated. All subjects were guided to become familiar with the experimental devices and process by testers and warmed up for one or two minutes. All the key points of subjects, including ear, shoulder, trochanter, knee, lateral malleolus, and fifth toe, were marked in turn (Figure 1).

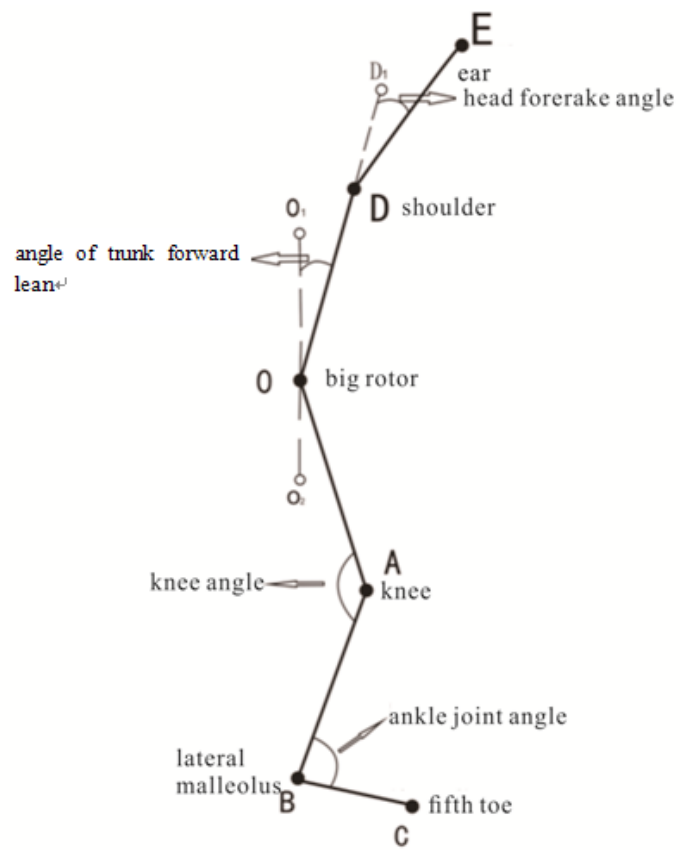

Figure 1. Graphic of Key Points of Codamotion

Plantar pressure test and CODA test were begun at the same time, all subjects were guided in walking with backpack loading of $5 \%, 10 \%$, $15 \%, 20 \%$ and $25 \%$ body weight respectively. Three successful measures for plantar pressure test and CODA test were required.

\section{Data Processing}

\section{COP Analysis}

Any COPi was composed by coordination in the $X$ and $Y$ direction ( $X i, Y i)$, as well as the time cost, hence, based on the coordination, we could calculate the minimum and maximum vibration in $X$ (Xmin and $X \max$ ) and $Y$ (Ymin and $Y$ max) axis. The distribution of COP was a theory 
value, hence COP even exists when there was no pressure in midfoot (Figure 2).

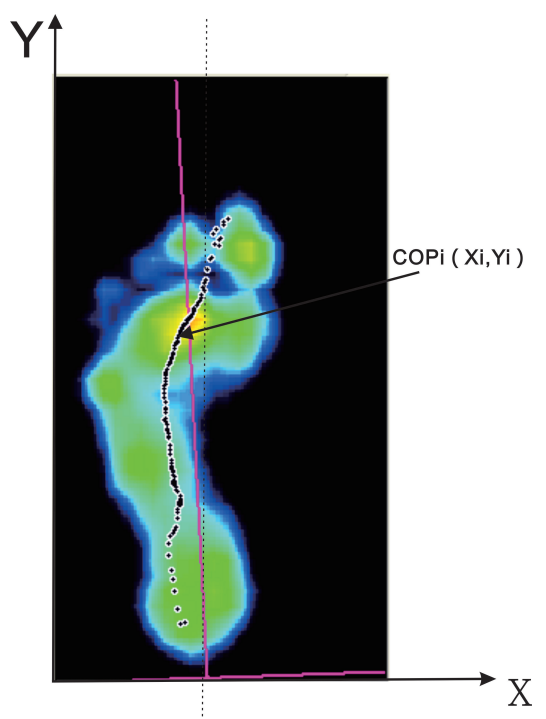

Figure 2. Trajectory of COP

On the basis of the analysis of the minimum in $X$ axis ( $X \min$ ), maximum in $X$ axis ( $X \max$ ) of COP and movement time, we got the deviation in $X$ and $Y$ axis (Dx, Dy) and relative deviation in $X$ and $Y$ axis (Dxrel, Dyrel) of COP, relative velocity (velocity and relative velocity in $\mathrm{X}$ axis: $\mathrm{Vx}, \mathrm{Vxrel}$; velocity and relative velocity in $Y$ axis: $V y, V y r e l)$, sum and relative sum distance in $X$ axis (SumX, SumXrel) and sum and relative sum distance in $Y$ axis (SumY, SumYrel). The procedures of normalization of deviation, velocity and sum distance were shown below:

$$
\begin{aligned}
& \text { Dx }=|X \max -X \min | \\
& \text { Dxrel }=|X \max -X \min | / F W \\
& \text { Dy }=|Y \max -Y \min | \\
& \text { Dyrel }=|Y \max -Y \min | / F L \\
& \text { Sum } X=\sum\left(X_{i+1}-X_{i}\right) \\
& \text { SumXrel }=\sum\left(X_{i+1}-X_{i}\right) / F W \\
& \text { SumY }=\sum\left(Y_{i+1}-Y_{i}\right) \\
& \text { SumYrel }=\sum\left(Y_{i+1}-Y_{i}\right) / F L \\
& \text { Vxrel }=\text { Dxrel } / \text { times } \\
& \text { Vyrel }=\text { Dyrel / times }
\end{aligned}
$$

\section{Vector Angle Analysis}

Vector angle showed the space relationship of joint and it was developed by the plane constituting by the key points of joint. Data of subjects during normal walking was recorded by CODA, the vector angles included head fore rake angles, body fore rake angles, knee joint angles and ankle joint angles were calculated via space location of key points. Vector angles were needed to calculate amplitude of angle and the time when the angle reached peak and the maximum angle.

\section{Statistical Analysis}

The measures of each test were first averaged; all data were divided into groups according to backpack load, and the data of each group averaged; then One-Sample KolmogorovSmirnov confirmed that all data were following with the normal distribution and the result showed that all data were following with the normal distribution; meanwhile independent $T$ test was used to verify if the data had significant differences between two feet and the results of independent $T$ test was verified that two feet had significant differences, so data of right foot was selected for analysis; One-Way ANOVA was used to analysis the COP and vector angle under different backpack loads. All the statistical models were operated under SPSS (16.0 V, SPSS Inc., Chicago, USA) with a significant level of 0.05 and $95 \%$ confidence interval.

\section{RESULTS}

\section{Result and Analysis of COP}

The result of ANOVA analysis of all parameters under different backpack loading (Table 2). 
Table 2: The Analysis Result of One Way ANOVA of COP

\begin{tabular}{|c|c|c|c|c|c|c|c|c|}
\hline \multirow{2}{*}{$\begin{array}{c}\text { Backpack } \\
\text { loading }\end{array}$} & \multicolumn{2}{|c|}{$X \min (\mathrm{mm})$} & \multicolumn{2}{|c|}{ Xmax (mm) } & \multicolumn{2}{|l|}{$Y \min (\mathrm{mm})$} & \multicolumn{2}{|l|}{ Ymax (mm) } \\
\hline & Mean & SD & Mean & SD & Mean & SD & Mean & SD \\
\hline $0 \% \mathrm{BW}$ & -10.1 & 4.4 & 19.6 & 5.3 & 22.4 & 7.2 & 214.4 & 20.2 \\
\hline $5 \%$ BW & -10.2 & 5.1 & 19.4 & 5.6 & 22.2 & 4.9 & 217.5 & 15.1 \\
\hline $10 \% \mathrm{BW}$ & -10.0 & 5.1 & 18.8 & 5.7 & 22.4 & 4.9 & 215.6 & 20.3 \\
\hline $15 \%$ BW & -10.1 & 5.3 & 18.5 & 6.0 & 22.3 & 5.6 & 215.6 & 19.6 \\
\hline $20 \%$ BW & -9.4 & 4.6 & 18.6 & 5.7 & 21.3 & 5.1 & 210.8 & 30.3 \\
\hline \multirow[t]{3}{*}{$25 \%$ BW } & -9.8 & 5.0 & 19.2 & 5.7 & 22.2 & 6.5 & 217.0 & 17.7 \\
\hline & \multicolumn{2}{|l|}{ V-X } & \multicolumn{2}{|l|}{ V-Y } & \multicolumn{2}{|l|}{ SumX (mm) } & \multicolumn{2}{|l|}{ SumY (mm) } \\
\hline & Mean & SD & Mean & SD & Mean & SD & Mean & SD \\
\hline $0 \% \mathrm{BW}$ & 0.094 & 0.019 & 0.317 & 0.042 & 58.7 & 12.6 & 198.1 & 22.0 \\
\hline $5 \%$ BW & 0.093 & 0.015 & 0.324 & 0.032 & 57.3 & 9.4 & 198.6 & 15.4 \\
\hline $10 \% \mathrm{BW}$ & 0.091 & 0.014 & 0.322 & 0.036 & 56.1 & 8.5 & 197.4 & 19.4 \\
\hline $15 \%$ BW & 0.092 & 0.016 & 0.318 & 0.037 & 57.3 & 10.7 & 197.0 & 18.9 \\
\hline $20 \%$ BW & 0.088 & 0.018 & 0.309 & 0.048 & 55.1 & 11.7 & 192.7 & 28.2 \\
\hline $25 \%$ BW & 0.089 & 0.015 & 0.314 & 0.036 & 56.8 & 10.2 & 199.1 & 18.7 \\
\hline
\end{tabular}

As shown in Table 2, Ymax of COP increased with the increasing of backpack loading, while Xmax of COP was in contrast, both of the changes were slight. The $P$ values of the groups were all larger than 0.05 in the range of $0.067 \sim 1$. Hence, there was no significant difference on COP between different backpack loading.

\section{Result of Joint Vector Angle Analysis}

As showed in Table 3, the reaching time of max angle increased with the increasing of backpack loading, 0 vs $25 \%$ BW P $=0.04,5 \%$ BW vs $20 \%$ BW P $=0.042,5 \%$ BW vs $20 \%$ BW $P=0.01$; compared with $0 \% \mathrm{BW}$, backpack loading reduced the angle of trunk forward lean, 0 vs $5 \%$ BW $P=0$, 0 vs $10 \%$ BW $P=0,0$ vs $15 \%$ BW $P=0,0$ vs $20 \%$ BW $P=0$; the increasing of backpack loading also reduced the knee angle, 0 vs $25 \% \mathrm{BW} P=0.036$; changes of ankle joint angle were the same as the knee angles. 0 vs $5 \%$ BW $P=0.013,0$ vs $15 \%$ BW $P=0.014,0$ vs $20 \%$ BW $P=0.01$, 0 vs $25 \%$ BW $P=0$; the range of movement increased significantly with the increasing of backpack loading, 0 vs $20 \%$ BW $P=0.01,0$ vs $25 \%$ BW $P=0.02$. 
Table 3: The Analysis Result of One Way ANOVA of CODA

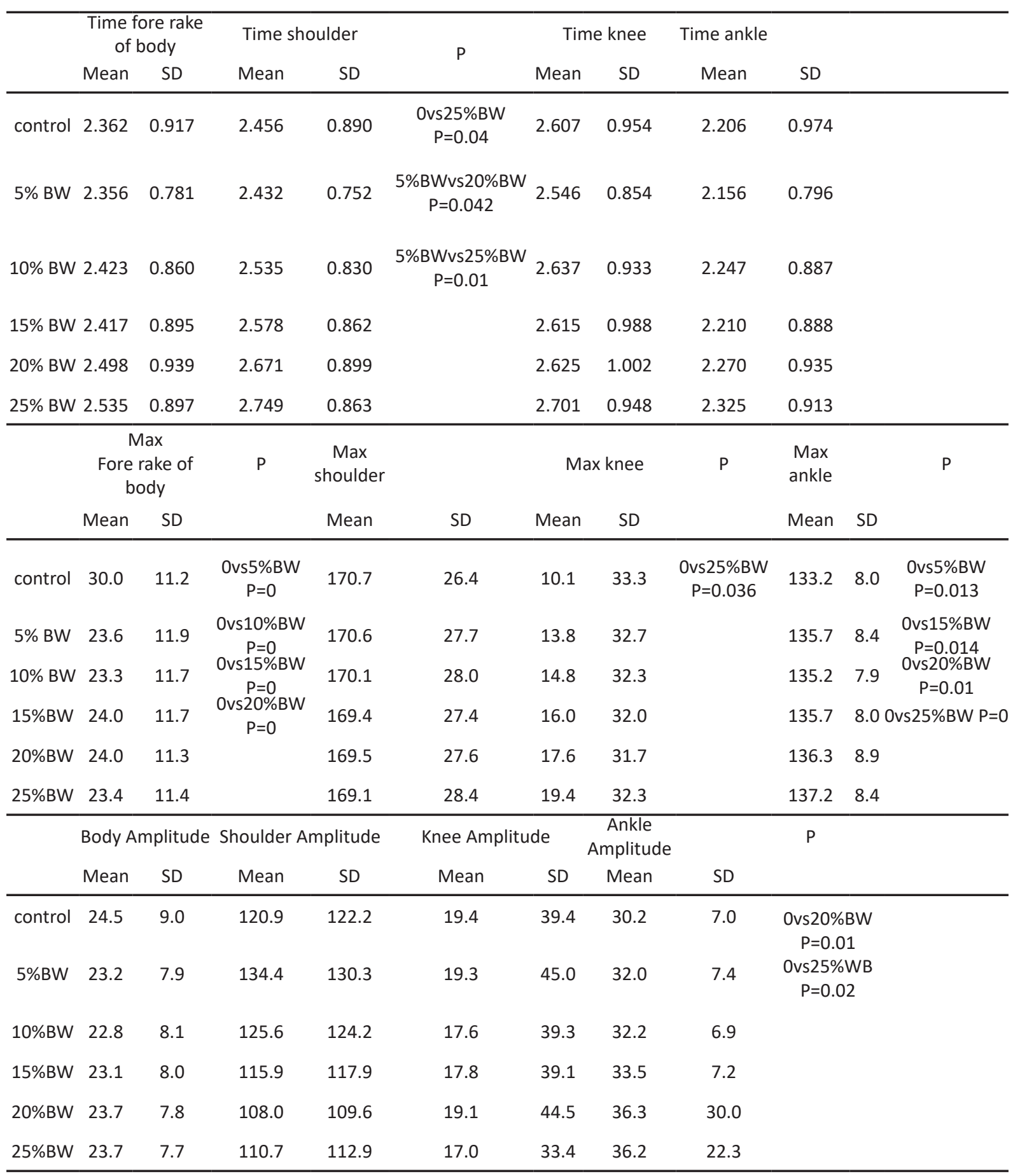

Note: the vector angle of shoulder/ knee/ ankle in table was the supplementary angle of it in Figure 1. 


\section{DISCUSSION}

Problems pertaining to overloading schoolchildren are a major concern. In this paper, parameters of center of pressure, front lean angle of head and trunk, vector angles within two lower limb joints and peak time of arrival angle were calculated to quantify the relationship between the loading and balance.

As you can see from the results, the increasing of backpack loading had no significant influence on COP, while it would increase the arrival time of peak value of all angles, and reduces the motion range of knee and ankle. We considered: on the one hand, the impact of weight on the various parameters of the COP was little, load increasing in pupils backpack has little influence on the movement balance when walking, pupils can respond to balance risk with the increase of the load. On the other hand, with the increase of the load, the time of the angle of trunk front lean reached the peak increased, and the parts of the knee and ankle movement amplitude decreased. It showed that children would adjust their posture to eliminate the risk factor from load increasing to maintain balance control. The increasing of backpack load changed the COP of the body, also increased moment of hip joint and contraction of abdominal muscle, and thereby weakened the ability of balance control. In order to control the balance of the body, children leaned forward to offset gravity loss of backward movement. Meanwhile, reduction of swing time and single support phase time were reduced.

In current literature, Hong et al. [4] showed that the increasing backpack loading increased the front rake angle of body significantly, especially the comparison between $15-20 \%$ BW and $0-10 \%$ BW. Range of motion of body decreased significantly when the loading was more than $20 \%$ BW. Hong et al. considered that preschoolers can quickly adapt to gait with the increasing of backpack loading. Malhotra and Sen Gupta [11] pointed out no significant changes in body posture at $10-20 \%$ BW loading. While the study of Pascoe et al. [12] found that carrying a two-strap backpack of $17 \%$ of the body weight of youths significantly promoted forward lean of head and trunk compared to walking without backpack. The past research suggests that load changed posture of body and affect motion balance. When the load was more than $15 \%$, changes of body position were significant. However, the number of the existing research samples was few and its regional distribution was not widespread. Our study was based on a large number of samples, and the experimental result was more universal. Our study also confirmed that $15 \%$ BW was the boundary and the parameters lower than $15 \%$ BW had significant difference with the parameters over it. 15\% BW was widely considered to be the safety loading value, and it had no significant influence on body position.

This study was the first to investigate the relationship between the load and movement balance from the center trajectories of pressure and body posture change. The parameters of center of pressure, front lean angle of head and trunk, vector angles within two lower limb joints and peak time of arrival angle were calculated to quantify the relationship between the loading and balance. The results showed that the impact of weight on the various parameters of the COP was not obvious, and pupils can deal with the balance risk of weight increase. In order to maintain balance control, children would adjust their posture to eliminate the risk factor from load increasing. 15\% BW was widely considered to be the safety loading value.

\section{CONCLUSION}

In our research, the increasing of backpack loading had no significant influence on COP, while it would increase the arrival time of peak value of all angles, and reduces the range of motion of knee and ankle. As a result, pupils can cope with the balance risk increased with the increase of load, and corresponding measures have been taken to eliminate related risk factors.

\section{Acknowledgments}

The authors would like to thank all participants for their full cooperation and support during the conduct of this study. The authors would also like to thank the colleagues of Guangzhou Shiling Leather \& Leather Products Investigation Center, for their assistance in recruiting study participants.

This study was funded by the financial support from Guangzhou Huadu district Science and Technology Project (HD12CXY-G0016). 


\section{Authors' Contributions}

YLM and CWY contributed to the conception, protocol development, and design of the study. ZJ and ZN participated in data acquisition, analysis, and interpretation. All authors have contributed significantly to the various stages in the writing of this manuscript and approved the final version of the paper. All authors agree with the order of presentation of the authors.

\section{Competing Interests}

None of the authors declare competing financial interests.

\section{REFERENCES}

1. Nan, Z., Wuyong, C., Luming, Y., Jin, Z., Application and Prospects of Biomechanical Analysis Technology in Design of Bag, Leather Science and Engineering, 2015, 25, 5, 27-32.

2. Min, W., Aming, L., Qiuxia, Z. et al., Research on the Influence of Backpack on the Balance, Posture and Gait of the Youngsters, Sport Science Research, 2015, 36, 2, 8-12.

3. Trevelyan, F.C., Legg, S.J., Back pain in school children-Where to from here?, Appl Ergon, 2006, 37, 45-54, https://doi.org/10.1016/j. apergo.2004.02.008.

4. Hong, Y., Brueggemann, G.P., Changes in gait patterns in 10-year-old boys with increasing loads when walking on a treadmill, Gait Posture, 2000, 11, 3, 254-259, https://doi. org/10.1016/S0966-6362(00)00055-2.

5. Nan, Z., Jin, Z., Luming, Y., Wuyong, C., Investigation of the Effect of Varied Schoolbag Weight on the Health of Primary Students: A Quantitative Plantar Pressure Study, Leather and Footwear Journal, 2015, 15, 3, 159-168, https://doi.org/10.24264/Ifj.15.3.3.

6. Pau, M.C., Borona, F., Leban, B. et al., Effects of backpack carriage on foot-ground relationship in children during upright stance, Gait Posture, 2011, 33, 2, 195-199, https:// doi.org/10.1016/j.gaitpost.2010.10.096.
7. Rugelj, D., Sevšek, F., The Influence of Load Placement on Postural Sway Parameters, $13^{\text {th }}$ International Conference on Biomedical Engineering, Springer Berlin Heidelberg, 2009, 1821-1824.

8. Rugelj, D., Sevšek, F., The effect of load mass and its placement on postural sway, Appl Ergon, 2011, 42, 42, 860-6, https://doi. org/10.1016/j.apergo.2011.02.002.

9. Singh, T., Koh, M., Effects of backpack load position on spatiotemporal parameters and trunk forward lean, Gait Posture, 2008, 29, 1, 49-53, https://doi.org/10.1016/j. gaitpost.2008.06.006.

10. Meyers-Rice, B.S.L., McPoil, T., Cornwall, M., Comparison of three methods for obtaining plantar pressures in no pathologic subjects, $J$ Am Podiatr Med Assoc, 1994, 499-504, https:// doi.org/10.7547/87507315-84-10-499.

11. Malhotra, M.S., Gupta, J.S., Carrying of school bags by children, Ergonomics, 1965, 8, 1, 55-60, https://doi. org/10.1080/00140136508930774.

12. Pascoe, D.D., Pascoe, D.E., Wang, Y.T. et al., Influence of carrying book bags on gait cycle and posture of youths, Ergonomics, 1997, 40, 6, 631-41, https://doi. org/10.1080/001401397187928.

(C) 2018 by the author(s). Published by INCDTP-ICPI, Bucharest, RO. This is an open access article distributed under the terms and conditions of the Creative Commons Attribution license (http://creativecommons. org/licenses/by/4.0/). 